\title{
PENERAPAN MODEL PEMBELAJARAN PBL DALAM MENINGKATKAN AKTIVITAS, MINAT, DAN HASIL BELAJAR EKONOMI PADA SISWA KELAS X (Studi Kasus Pada SMA Negeri 1 Bengkayang)
}

\author{
Pebria Dheni Purnasari $^{1)}$ dan Yosua Damas Sadewo ${ }^{2)}$ \\ ${ }^{1}$ Manajemen, Sekolah Tinggi Ilmu Manajemen \\ ${ }^{2}$ Kewirausahaan, Sekolah Tinggi Ilmu Manajemen \\ 1,2, Jalan Bukit Karmel No 1, Bengkayang, 7921, Kalimantan Barat \\ E-mail : pebria.dheni@shantibhuana.ac.id ${ }^{1)}$, yosua.damas@shantibhuana.ac.id ${ }^{2)}$
}

\begin{abstract}
ABSTRAK
Tujuan dari penelitian ini adalah untuk meningkatkan aktivitas, minat dan hasil belajar siswa kelas X SMA N 1 Bengkayang pada mata pelajaran ekonomi setelah mengikuti pembelajaran dengan model PBL. Penelitian ini merupakan penelitian tindakan kelas (PTK) yang dilakukan dalam 2 siklus dan masing-masing siklus terdiri dari 3 pertemuan. Penelitian ini dilakukan di kelas X SMA N 1 Bengkayang. Teknik pengumpulan data menggunakan teknis tes, observasi, dan angket, sedangkan analisis data menggunakan analisis deskriptif kuantitatif. Teknik tes digunakan untuk mengukur hasil belajar siswa, observasi dilakukan guna mengetahui aktivitas siswa dalam mengikuti pembelajaran, dan angket digunakan untuk mengukur minat belajar siswa selama mengikuti pembelajaran dengan model PBL. Adapun hasil penelitian ini menunjukkan adanya peningkatan ketuntasan hasil belajar, minat belajar dan aktivitas belajar dari kondisi awal hingga ke siklus II. Peningkatan hasil belajar yang didapat pada siklus II telah mencapai indikator keberhasilan yang ditentukan yakni hasil belajar pada siklus II sebesar meningkat menjadi 88,24\% dari siklus I yakni 70,59\%, sedangkan minat belajar siswa siklus I sebesar 67,65\% meningkat menjadi 78,16 \% pada siklus II dan aktivitas belajar siswa sebesar $80 \%$ pada siklus I meningkat menjadi $92,5 \%$ pada siklus II. Peningkatan tersebut menunjukkan keberhasilan penerapan model pembelajaran PBL, dengan demikian dapat disimpulkan bahwa peningkatan aktivitas, minat, dan hasil belajar ekonomi siswa melalui model pembelajaran PBL telah berhasil dilakukan.
\end{abstract}

Kata Kunci: hasil belajar, minat belajar, aktivitas belajar, model PBL, pendidikan ekonomi.

\section{PENDAHULUAN}

Perkembangan pendidikan tidak lepas dari peran serta manusia. Manusia merupakan subjek sekaligus objek bagi pendidikan itu sendiri. Pendidikan yang unggul menjadi arah dari perjalanan pendidikan di Indonesia, namun tidak akan berhenti pada tercapainya pendidikan yang unggul semata melainkan akan terus berkembang seiring dengan kebutuhan manusia dan perkembangan jaman. (Peraturan Pemerintah Republik Indonesia Nomor 17, Tahun 2010) tentang Pengelolaan dan Penyelenggaraan Pendidikan menyebutkan bahwa Sekolah Mengengah Atas yang disingkat SMA merupakan salah satu bentuk satuan pendidikan formal yang menyelenggarakan pendidikan umum pada jenjang pendidikan menengah sebagai lanjutan dari SMP, MTs, atau bentuk lain yang sederajat atau lanjutan dari hasil belajar yang diakui sama/ setara SMP atau MTs. Pendidikan SMA diberikan secara khusus sebagai lanjutan pendidikan formal dan menyandang tujuan pendidikan nasional yakni untuk meningkatkan kecerdasan, pengetahuan, kepribadian, akhlak mulia, serta keterampilan untuk hidup mandiri dan meningkuti pendidikan lebih lanjut. Pendidikan SMA merupakan bagian dari pendidikan wajib selama 12 tahun. Kajian ilmu yang diberikan tentu lebih luas dan mendalam jika dibanding dengan jenjang pendidikan dasar dan menengah pertama. Ditinjau dari tahap perkembangan, siswa pada tahap perkembangan di jenjang SMA tergolong sebagai manusia yang menginjak tahap dewasa, sehingga telah mampu berpikir secara rasional, logis dan serta memahami pola-pola yang abstrak. Pada tahap ini pemahaman terhadap objek pembelajaran yang abstrak tidak sulit untuk dimengerti sehingga kajian pembelajaran tingkat SMA bersifat abstrak. Langkah untuk menggapai tujuan tersebut secara jelas tergambarkan dalam pengelolaan kurikulum pendidikan SMA, di mana (Peraturan Pemerintah Republik Indonesia Nomor 32, Tahun 2013) tentang Satuan Pendidikan Nasional menyebutkan secara spesifik daftar mata pelajaran yang menjadi muatan umum jenjang pendidikan SMA, salah satunya adalah Ilmu Pengetahuan Sosial. Salah satu kajian ilmu dalam Ilmu Pengetahuan Sosial adalah Mata Pelajaran Ekonomi.

Ilmu Ekonomi merupakan ilmu yang mengkaji kebutuhan dan bagaimana memenuhi kebutuhan tersebut (Eko, 2016). Kajian tersebut merupakan cakupan materi 
dalam pembelajaran ekonomi di SMA. Bahasan ilmu ekonomi berkaitan dengan kegiatan manusia dalam kehidupan sehari-hari. Melekatnya ekonomi dalam diri manusia dapat diketahui melalui kegiatan rutinitas manusia dalam kehidupan sehari-hari, terutama pada kegiatan untuk memenuhi kebutuhannya (Murdinar, Wahyono, \& Haryono, 2017). Pemaparan tersebut menunjukkan bahwa ilmu ekonomi merupakan salah satu ilmu yang perlu dipelajari terkhusus di jenjang SMA, di mana ilmu ini tidak sekedar memberikan pengetahuan namun juga meningkatkan keterampilan hidup. Pada dasarnya setiap mata pelajaran yang ditetapkan pada jenjang pendidikan memiliki tingkat kesulitan tersendiri dan menjadi penting sesuai tujuan dari kajian pada masing-masing ilmu, begitu juga dengan ilmu ekonomi yang dikemas dalam mata pelajaran ekonomi. Layaknya pembelajaran pada umumnya, mata pelajaran ekonomi dalam rangkaian proses pembelajaran memiliki tingkat kesulitan tersendiri. Menelaah dari berbagai penelitian yang telah dilakukan ditemui bahwa permasalahan seputar rendahnya hasil belajar ekonomi bukan menjadi hal baru. (Mastufah, 2019) melalui penelitiannya mengemukakan bahwa didapati permasalahan yakni hasil belajar siswa pada mata pelajaran ekonomi rendah. Tidak jauh berbeda dengan hal tersebut, rendahnya hasil belajar siswa pada pelajaran ekonomi juga menjadi permasalahan yang diungkapkan dalam penelitian dari (Inayah, Martono, \& Sawiji, 2013).

Permasalahan terkait rendahnya hasil belajar khususnya pada mata pelajaran ekonomi juga ditemui pada siswa kelas X di SMA N 1 Bengkayang. Penelitian ini berangkat dari hasil observasi yang dilakukan peneliti pada saat proses pembelajaran mata pelajaran Ekonomi di kelas X SMA Negeri 1 Bengkayang berlangsung. Temuan lapangan menunjukkan bahwa proses pembelajaran menggunakan metode ekspositori yakni guru memaparkan materi selanjutnya siswa diminta mengerjakan tugas yang ada di LKS (Lembar Kerja Siswa). Selama proses pembelajaran berlangsung terlihat siswa kurang aktif, hanya ada 3 siswa yang terlihat aktif dalam kegiatan tanya jawab. Selanjutnya untuk mengetahui permasalah yang lebih mendalam maka dilakukan wawancara tak berstruktur terhadap guru mata pelajaran dan diperoleh data bahwa ketuntasan belajar siswa hanya mencapai $47,06 \%$ dengan total 34 siswa, sehingga terdapat 52,94\% siswa atau sebanyak 18 siswa dari 34 siswa yang belum tuntas pada mata pelajaran Ekonomi di kelas X SMA N 1. Dari penuturan guru menunjukkan bahwa inovasi proses pembelajaran jarang dilakukan, pembelajaran kelompok juga belum pernah dilakukan. Meninjau hal tersebut, diduga rendahnya hasil belajar siswa disebabkan model pembelajaran yang bersifat monoton sehingga aktivitas siswa dalam proses pembelajaran juga rendah.

Rendahnya hasil belajar siswa dipengaruhi oleh berbagai faktor, salah satu faktor yang memiliki peran besar dalam mempengaruhi hasil belajar adalah proses pembelajaran. Proses pembelajaran erat kaitannya dengan model maupun metode ajar yang digunakan oleh guru. Guru memegang peranan utama dalam merancang proses pembelajaran. Seorang guru juga harus mampu merancang pembelajaran yang menyenangkan untuk siswa sehingga menimbulkan antusias dalam belajar (Nur, 2018). Kualitas pembelajaran yang baik bergantung pada bagaimana guru mampu merancang dan melaksanakan pembelajaran sehingga proses tersebut dapat diikuti oleh siswa, dengan demikian perbaikan kualitas pendidikan berpijak dari guru dan berujung pada guru juga (Mulyasa, 2009). Pemilihan model pembelajaran yang tepat perlu dilakukan guru guna menciptakan proses pembelajaran yang efektif, efisien dan menarik sehingga hal ini akan turut membantu tercapainya tujuan pembelajaran juga mampu mengatasi persoalan seputar proses belajar yang berujung pada rendahnya hasil belajar. Kondisi ini sebagaimana diungkapkan oleh (Naisyah, 2019) bahwa salah satu faktor penentu keberhasilan proses belajar ditentukan oleh penerapan model atau metode mengajar yakni bagaimana guru menyampaikan materi yang diajarkan. Meninjau hal tersebut, maka upaya yang dilakukan untuk mengatasi permasalahan rendahnya aktivitas dan hasil belajar siswa pada kelas X SMA N 1 Bengkayang adalah dengan menerapkan model pembelajaran yang mampu meningkatkan aktivitas siswa salah satunya adalah model Problem Based Learning.

Model Pembelajaran Berbasis Masalah atau Problem Based Learning yang selanjutnya disebut PBL adalah model pembelajaran melalui kegiatan kelompok untuk mengerjakan dan menyelesaikan suatu masalah dalam pembelajaran. Model PBL efektif untuk meningkatkan kemampuan berpikir melalui pemecahan masalah yang diberikan. Hal ini melatih siswa dalam menerapkan pengetahuan yang dimiliki atau berusaha mendapatkan pemahaman mengenai pengetahuan yang diberikan (Magdalena, 2016). Salah satu keunggulan PBL dinilai merupakan salah satu model pembelajaran yang sangat baik dalam mengembangkan berbagai keterampilan dasar yang harus dimiliki siswa termasuk keterampilan berpikir, keterampilan membuat keputusan, kemampuan berkreativitas, kemampuan memecahkan masalah, dan sekaligus dipandang efektif untuk mengembangkan rasa percaya diri, manajemen diri para siswa, serta kemampuan berkomunikasi. (Janah, et al., 2018) memaparkan bahwa model PBL merupakan model yang mengkondisikan kegiatan pembelajaran dengan menekankan kepada proses keterlibatan siswa secara penuh untuk dapat menemukan materi yang dipelajari dan menghubungkan dengan kehidupan sehari-hari. PBL merupakan model pembelajaran yang menggunakan masalah sebagai media, sehingga proses pembelajaran mengkondisikan siswa untuk aktif berpikir guna menyelesaikan masalah. Selain itu pemilihan PBL juga didasarkan pada proses pembelajaran yang belum pernah dilaksanakan. Artinya, model PBL belum pernah diterapkan oleh guru pada pembelajaran ekonomi. Meskipun demikian, selain berpijak dari konsep model 
PBL, pemilihan PBL juga didasarkan pada hasil penelitian terdahulu di mana model PBL telah terbukti memberi dampak positif pada hasil belajar. Hasil penelitian dari (Apriyani, et al., 2019) menunjukkan bahwa penerapan model PBL berpengaruh positif terhadap hasil belajar siswa. Temuan serupa juga ditunjukkan oleh penelitian dari (Rahmat, 2018) yakni melalui penerapan model PBL terbukti dapat meningkatkan hasil belajar siswa. Selain hasil belajar, model PBL juga terbukti meningkatkan aktivitas belajar siswa, hal ini dibuktikan melalui penelitian yang dilakukan oleh (Naisyah, 2019). Berpijak dari paparan tersebut, dan dengan memperhatikan hasil beberapa penelitian yang telah dipaparkan di atas maka model PBL dipilih untuk mampu meningkatkan hasil dan aktivitas belajar siswa, selain itu untuk mengetahui bahwa siswa tertarik mengikuti proses pembelajarn dengan model PBL maka juga dilakukan pengukuran terhadap minat belajar. Meskipun hasil penelitian terdahulu telah menunjukkan adanya peningkatan yang signifikan namun penggunaan model PBL pada penelitian-penelitian terdahulu dilakukan tanpa menggunakan bantuan media atau alat peraga, berbeda halnya dengan penelitian ini di mana pelaksanaan pembelajaran dengan menggunakan model PBL dipadukan dengan menggunakan media powerpoint. Hal ini dilakukan untuk menarik perhatian siswa. Selain subjek penelitian yang berbeda, penekanan kegiatan belajar kelompok pada model PBL yakni dengan melibatkan keaktifan seluruh anggota kelompok dalam merancang laporan diskusi, pemberian reward, dan penambahan media powerpoint menambah kekhasan dalam penelitian ini, sehingga dapat memberikan temuan baru.

\section{RUANG LINGKUP}

Berdasarkan pemaparan latar belakang di atas maka rumusan masalah dalam penelitian ini meliputi:

1. Apakah penerapan model PBL dapat meningkatkan hasil belajar ekonomi siswa kelas X SMA N 1 Bengkayang?

2. Apakah penerapan model PBL dapat meningkatkan $\begin{array}{llllll}\text { aktivitas belajar siswa kelas } & \mathrm{X} & \text { SMA } & \mathrm{N} & 1\end{array}$ Bengkayang?

3. Apakah penerapan model PBL dapat meningkatkan minat belajar siswa kelas X SMA N 1 Bengkayang?

\section{BAHAN DAN METODE}

Penelitian ini berfokus pada peningkatan aktivitas, minat, dan hasil belajar ekonomi siswa kelas $\mathrm{X}$ pada SMA N 1 Bengkayang. Aktivitas belajar merupakan kegiatan yang dilakukan oleh siswa dalam serangkaian proses pembelajaran. Aktivitas belajar juga diartikan sebagai kegiatan atau aktivitas yang dilakukan oleh siswa selama proses belajar berlangsung dengan tujuan mencapai hasil belajar yang diinginkan. Aktivitas ini berupa serangkaian kegiatan menanya, menyatakan pendapat, memberi jawaban atas pertanyaan yang diberikan, serta memperhatikan penjelasan yang dilakukan oleh guru (Purnamasari, 2016). Berdasarkan paparan tersebut, maka aktivitas belajar merupakan seluruh kegiatan yang dilakukan siswa selama proses pembelajaran berlangsung.

Minat belajar merupakan dorongan seseorang untuk melakukan sesuatu, dorongan ini menjadi landasan yang penting bagi seseorang dalam melakukan suatu kegiatan dengan baik (Purwanto, 2017). Sedangkan (Slameto, 2015) memaparkan bahwa minat merupakan sebuah penerimaan hubungan antara diri sendiri dengan sesuatu yang berasal dari luar diri. Definisi ini menunjukkan bahwa minat merupakan sesuatu yang ada dalam diri seseorang dan dapat ditumbuhkan dengan sesuatu yang berasal dari luar diri, dengan demikian dalam hal ini minat belajar siswa dalam belajar ekonomi akan dilihat peningkatannya setelah mengikuti proses belajar dengan penerapan model PBL. Siswa yang memiliki minat belajar akan mampu mengikuti proses pembelajaran dengan rasa senang, ada rasa tertarik terhadap belajar, memusatkan perhatianpada guru, bahkan mampu meningkatkan keaktifan siswa di kelas selama proses pembelajaran berlangsung (Putri, et al., 2017).

Hasil belajar merupakan suatu ketercapaian dari tujuan pembelajaran yang ditetapkan baik berupa kognitif, afektif, maupun psikomotorik. Ketercapaian hasil belajar tersebut merupakan hasil dari proses pembelajaran yang dapat berdampak pada perubahan tingkah laku serta peningkatan kemampuan dan keterampilan (Purnamasari, 2016). Hasil belajar yang diperoleh dari serangkaian proses belajar pada dasarnya dipengaruhi oleh 2 faktor yakni faktor intern dan eksteren. Meninjau pengertian tersebut, maka hasil belajar merupakan capaian pembelajaran yang diperoleh setelah siswa mengikuti proses pembelajaran, hasil belajar dapat dipengaruhi oleh berbagai faktor, diantarnya model pembelajaran sebagai faktor ekstern (Slameto, 2015). Salah satu faktor ekstern yang mempengaruhi hasil belajar adalah metode maupun model yang digunakan selama proses pembelajaran berlangsung. Berdasarkan hal tersebut, maka penerapan model PBL dalam proses pembelajaran akan dapat berpengaruh terhadap hasil belajar siswa. Pemilihan model PBL sendiri didasarkan atas substansi model PBL serta bukti bahwa model PBL berhasil dalam meningkatkan hasil belajar.

PBL didefinisikan sebagai model pembelajaran yang memfokuskan pada kegiatan belajar yang berdasar pada pemecahan masalah. Kegiatan tersebut mendorong berkembangnya kemampuan berpikir, hal ini dikarenakan siswa harus mampu memecahkan permasalahan yang diberikan. (Janah, et al., 2018) memaparkan bahwa model PBL merupakan model pembelajaran yang mendorong siswa untuk terlibat aktif dalam kegiatan pembelajaran seperti menghubungkan materi dalam kehidupan sehari-hari. PBL juga mampu meningkatkan pemahaman siswa terkait materi ajar, serta 
meningkatkan keterampilan pemecahan masalah yang disesuaikan dengan materi ajar (Rusman, 2016).

Jenis penelitian yang digunakan adalah penelitian tindakan kelas (PTK) yang dilakukan dalam 2 siklus. Setiap siklus terdiri dari 2 pertemuan yang meliputi kegiatan: planning (perencanaan), acting \& observating (tindakan dan pengamatan), reflecting (refleksi), dan revise plan (perbaikan rencana), di mana setiap siklus terdiri dari 3 pertemuan. Setiap pertemuan memuat pelaksanaan pembelajaran menggunakan model PBL yang dilakukan dengan berbantuan media powerpoint sekaligus dilakukan observasi atau pengamatan, selanjutnya dilakukan refleksi untuk mengulas kegiatan yang telah dilakukan. Hal ini diterapkan guna mengetahui kekurangan atau kendala pelaksanaan pada setiap pertemuan di masing-masing siklus sehingga dapat disusun upaya perbaikan. Setelah dilakukan pelaksanaan pembelajaran, di akhir siklus dilakukan tes evaluasi untuk mengukur hasil belajar serta minat siswa. Adapun aktivitas siswa diukur melalui kegiatan observasi di setiap pertemuan. Adapun tahapan penelitian ini dijelaskan pada Gambar 1.

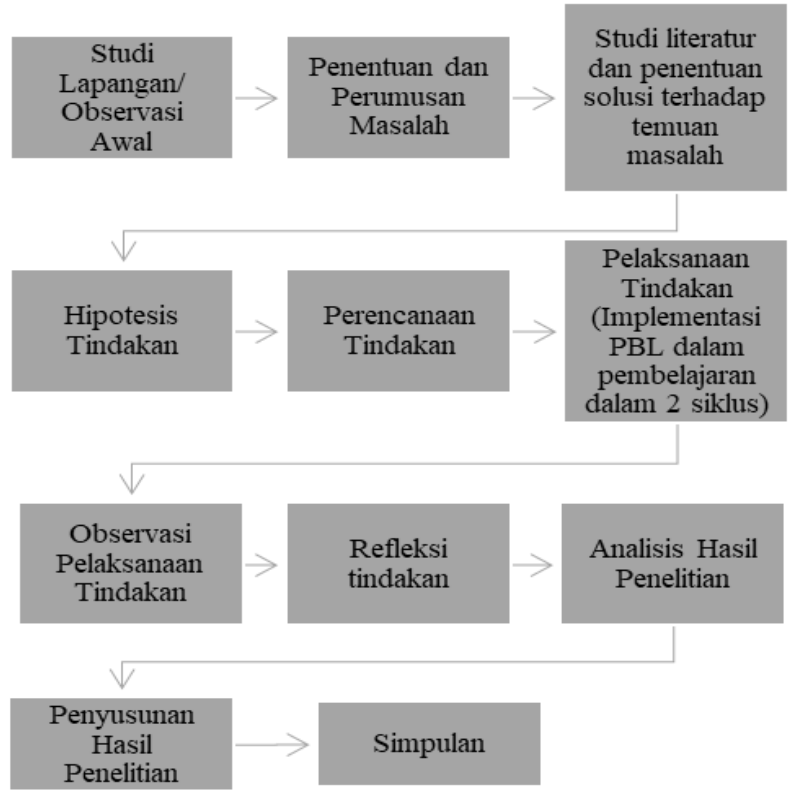

Gambar 1 Tahap Penelitian

Tujuan penelitian dalam PTK ini adalah terjadi peningkatan aktivitas belajar, minat dan hasil belajar siswa pada mata pelajaran ekonomi melalui penerapan model pembelajaran PBL pada siswa kelas X SMA Negeri 1 Bengkayang. Teknik yang digunakan untuk pengumpulan data yaitu dengan: (1) Tes yang dilakukan oleh peneliti berupa pre-test dan post-test untuk melihat hasil belajar siswa terhadap pembelajaran PBL; (2) Observasi dilakukan untuk mengamati proses pembelajaran, hal ini dilakukan untuk mengukur aktivitas siswa di kelas selama kegiatan pembelajaran PBL dilaksanakan; (3) Angket yang diberikan kepada siswa sebagai subjek penelitian untuk mengetahui minat belajar siswa setelah mengikuti pembelajaran dengan model PBL; (4) Catatan lapangan yang dilakukan bersamaan dengan implementasi tindakan berisi tentang hal-hal yang terjadi selama berlangsungnya pembelajaran yang tidak terekam dalam lembar observasi; (5) Dokumentasi yang meliputi nilai siswa sebelum diberi tindakan, RPP, dan gambar atau foto selama berlangsungnya penelitian tindakan kelas.

Analisis data dalam penelitian ini dengan menggunakan analisis deskriptif kuantitatif dan deskriptik kualitatif. Melalui hasil analisis ini akan diketahui tingkat keberhasilan pelaksanaan penerapan model pembelajaran PBL dalam meningkatkan aktivitas belajar, dan hasil belajar siswa yang dilakukan pada setiap siklus, serta dilakukan pengukuran minat belajar siswa.

\section{PEMBAHASAN}

Berikut dijabarkan hasil dan pembahasan dalam penelitian ini

\subsection{Kondisi Awal}

Kondisi pra siklus merupakan kondisi ketuntasan belajar siswa kelas X di SMA N 1 Bengkayang di mana kondisi ini merupakan kondisi sebelum diterapkan model pembelajaran PBL pada pelajaran Ekonomi. Pada kondisi ini, diketahui bahwa ketuntasan belajar siswa tidak mencapai indikator keberhasilan, di mana indikator keberhasilan yang ditentukan adalah $80 \%$ siswa atau 29 siswa dari 34 siswa mengalami ketuntasan belajarnya. Namun, melalui tes yang diberikan menunjukkan siswa yang tuntas belajarnya hanya 16 siswa sedangkan 18 siswa lainnya dinyatakan tidak tuntas. Meninjau kondisi tersebut, selain ketuntasan yang jauh dari indikator keberhasilan, diketahui juga jumlah siswa yang tuntas lebih sedikit dibanding jumlah siswa tidak tuntas. Oleh karena itu, diperlukan upaya untuk meningkatkan hasil belajar siswa, dalam hal ini upaya yang dilakukan adalah dengan menerapkan pemblajaran PBL pada mata pelajaran ekonomi di kelas X. Adapun presentase ketuntasan siswa pada kondisi pra siklus di sajikan pada Tabel 1.

Tabel 1 Ketuntasan Hasil Belajar Siswa Kelas X SMA N 1 Bengkayang Pra Siklus

\begin{tabular}{|c|c|c|}
\hline Kategori & Frekuensi & Persenntase \\
\hline Tuntas & 16 & 47,06 \\
\hline Tidak Tuntas & 18 & 52,94 \\
\hline Total & 34 & 100 \\
\hline Nilai Max & \multicolumn{2}{|c|}{85} \\
\hline Nilai Min & \multicolumn{2}{|c|}{30} \\
\hline Rata-Rata & \multicolumn{2}{|c|}{67,65} \\
\hline
\end{tabular}

Berdasarkan Tabel 1, serta penjabaran di atas, maka diketahui bahwa ketuntasan siswa berada pada kategori yang rendah, di mana ketuntasan siswa tidak mencapai 50\%. Permasalahan lain juga ditemui, selain hasil belajar yang rendah didapati juga bahwa minat belajar siswa yang tergolong rendah. Melalui hasil pengamatan dan wawancara tak terstruktur, didapati 
bahwa siswa cenderung kurang berminat untuk mengikuti pembelajaran yang monoton, hal ini juga berakibat pada kurangnya aktivitas siswa pada pembelajaran. Oleh karena itu diperlukan suatu pembelajaran yang dapat meningkatkan permasalahan tersebut, melalui hasil studi literatur maka peneliti memilih menerapkan model pembelajaran PBL. Model pembelajaran PBL dalam penelitian ini diterapkan selama proses pembelajaran berlangsung yakni selama 2 siklus.

\subsection{Siklus I}

Pelaksanaan pembelajaran siklus I berjalan dengan cukup baik, meskipun terdapat beberapa kendala yakni ada beberapa langkah pembelajaran yang tersusun dalam RPP terlewatkan. Proses pembelajaran belum berjalan secara kondusif di mana kondisi kelas masih ramai. Hal ini dikarenakan pembelajaran kelompok jarang dilakukan. Namun secara keseluruhan pembelajaran telah berjalan dengan baik. Pada pembelajaran kelompok, guru telah membimbing siswa sehingga siswa tidak kesulitan dalam menyusun laporan. Adanya media powerpoint sangat membantu guru untuk memberikan penjelasan materi serta menarik minat siswa untuk mendengarkan dan tetap fokus pada materi yang dijelaskan guru. Kondisi demikian juga terjadi pada pertemuan 2 siklus I, yakni penjelasan materi dapat dilakukan dengan mudah melalui bantuan media powerpoint, kendala pada pertemuan 1 sudah mulai dapat diatasi, hanya saja masih ada langkah pembelajaran yang terlewatkan namun kondisi pembelajaran pertemuan 2 jauh lebih baik pada pertemuan 1.

Selanjutnya setelah siswa mengikuti seluruh rangkaian pembelajaran pada siklus I, dilakukan tes evaluasi siklus untuk mengukur hasil belajar siswa. Hasil tes evaluasi siklus I disajikan pada Tabel 2.

Tabel 2 Ketuntasan Hasil Belajar Siklus I

\begin{tabular}{|c|c|c|c|}
\hline No & Kategori & Frekuensi & Persenntase \\
\hline 1 & Tuntas & 24 & $70,59 \%$ \\
\hline 2 & Tidak Tuntas & 10 & $29,41 \%$ \\
\hline \multicolumn{2}{|c|}{ Total } & 34 & $100 \%$ \\
\hline & Nilai Max & \multicolumn{2}{|c|}{85} \\
\hline & Nilai Min & \multicolumn{2}{|c|}{50} \\
\hline & Rata-Rata & \multicolumn{2}{|c|}{73,24} \\
\hline
\end{tabular}

Tabel 2 menunjukkan bahwa jumlah siswa yang tuntas lebih banyak dibandingkan dengan jumlah siswa yang tidak tuntas yakni 70,59\% dari seluruh siswa mengalami ketuntasan belajar. Hasil ketuntasan siklus I jika dibandingkan dengan kondisi awal yakni kondisi sebelum diterapkannya model pembelajaran PBL, maka dapat diketahui bahwa adanya peningkatan ketuntasan dari kondisi sebelumnya. Namun ketuntasan belajar pada siklus I belum mencapai indikator keberhasilan yang ditentukan, oleh karena itu diperlukan upaya perbaikan yang diimplementasikan dalam siklus II.
Untuk menggambarkan ketuntasan pada siklus I, maka disajikan diagaram ketuntasan hasil belajar pada Gambar 2.

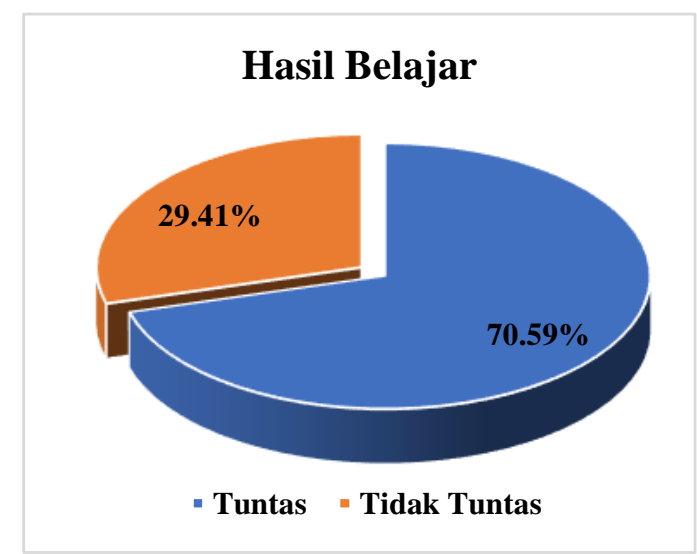

\section{Gambar 2 Persentase Ketuntasan Belajar Siklus I}

Perbandingan hasil belajar siswa setelah diadakan tindakan pada siklus I sebagaimana disajikan pada Gambar 1, menunjukkan perbedaan jumlah siswa yang tidak tuntas dengan siswa yang tuntas. Melalui Gambar 2, terlihat bahwa jumlah siswa yang tuntas jauh lebih banyak dibandingkan siswa yang tidak tuntas. Hal ini menunjukkan bahwa penerapan model pembelajaran PBL telah terlaksana dan dapat diikuti dengan baik oleh siswa maupun guru. Meskipun ketuntasan belum mencapai indikator kinerja, namun nilai ketuntasan pada siklus I lebih baik dibandingkan pada kondisi sebelumnya yakni kondisi sebelum PBL diterapkan.

Aktivitas siswa yang diamati adalah aktivitas siswa selama mengikuti pembelajaran dengan menggunakan model PBL. Penghitungan aktivitas siswa dilakukan dengan menggunakan sistem (1) berikut.

$$
\text { Nilai }=\frac{\Sigma \text { Skor yang diperoleh }}{\Sigma \text { Skor maksimum }} \times 100 \%
$$

Dengan kriteria nilai sebagai berikut:

80 ke atas : amat baik

$70-79 \quad$ : baik

56-69 : cukup

55 ke bawah : kurang

Aktivitas siswa dalam mengikuti pembelajaran dengan model PBL disajikan pada Tabel 3.

Tabel 3 Hasil Observasi Aktivitas Siswa Mengikuti Pelajaran Menggunakan Model PBL Siklus I

\begin{tabular}{|c|c|c|c|}
\hline Pertemuan & $\begin{array}{c}\text { Total } \\
\text { skor }\end{array}$ & $\begin{array}{c}\text { Nilai } \\
\text { Aktivitas }\end{array}$ & Kriteria \\
\hline 1 & 15 & $75 \%$ & Baik \\
\hline 2 & 17 & $85 \%$ & Amat Baik \\
\hline Rata-Rata & $\mathbf{1 6}$ & $\mathbf{8 0 \%}$ & Amat Baik \\
\hline
\end{tabular}

Berdasarkan hasil pada Tabel 3, dapat diketahui bahwa aktivitas siswa dalam mengikuti pembelajaran 
pada siklus I pertemuan 1 masuk dalam kriteria baik, dan pada pertemuan 2 berada pada kategori baik sekali. Berdasarkan Tabel 4.3, juga dapat diketahui bahwa adanya peningkatan aktivitas sebesar $10 \%$. Berdasarkan hasil tersebut, maka aktivitas siswa pada siklus I setelah dirata-rata berada pada kategori amat baik dengan persentase $80 \%$.

Minat siswa selama mengikuti pembelajaran dengan model PBL diukur melalui angket yang diberikan di setiap akhir siklus. Minat belajar siswa yang diukur melalui angket, kemudian dianalisis.

Setelah dilakukan analisis terhadap minat siswa setelah mengikuti pembelajaran PBL pada siklus I diketahui bahwa minat belajar siswa mencapai $67,65 \%$. Nilai tersebut berada pada kategori cukup.

\subsection{Siklus II}

Pembelajaran pada siklus II telah berjalan dengan lancar. Kendala yang di alami pada pertemuan siklus I telah teratasi dengan baik pada siklus II. Kondisi belajar pada siklus II jauh lebih kondusif, guru dapat mengontrol suasana kelas dan setiap siswa dapat berkontribusi secara aktif pada kegiatan kelompok. Adapun evaluasi hasil belajar pada siklus II disajikan pada Tabel 4.

Tabel 4 Ketuntasan Hasil Belajar Siklus II

\begin{tabular}{|c|c|c|c|}
\hline No & Kategori & Frekuensi & Persenntase \\
\hline 1 & Tuntas & 30 & $88,24 \%$ \\
\hline 2 & Tidak Tuntas & 4 & $11,76 \%$ \\
\hline \multicolumn{2}{c|}{ Total } & 34 & $100 \%$ \\
\hline & Nilai Max & \multicolumn{2}{|c|}{95} \\
\hline \multicolumn{2}{|c|}{ Nilai Min } & \multicolumn{2}{|c|}{77,79} \\
\hline \multicolumn{2}{|}{} \\
Rata-Rata & \multicolumn{2}{|c|}{} \\
\hline
\end{tabular}

Ketuntasan hasil belajar siklus II yang disajikan pada Tabel 4 menunjukkan jumlah siswa yang tuntas jauh lebih banyak dari pada jumlah siswa yang tidak tuntas. Berdasarkan paparan Tabel 4 juga diketahui bahwa ketuntasan pada siklus II telah melampaui indikator keberhasilan yang ditentukan. Hasil ini menunjukkan bahwa, penerapan model pembelajaran PBL pada kelas X SMA N 1 Bengkayang telah meningkatkan hasil belajar siswa pada mata pelajaran ekonomi.

Untuk menggambarkan ketuntasan pada siklus II, maka disajikan diagaram ketuntasan hasil belajar pada Gambar 3.

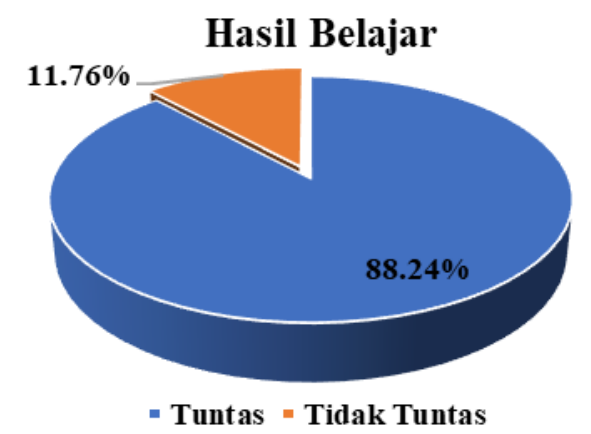

\section{Gambar 3 Persentase Ketuntasan Belajar Siklus II}

Perbandingan hasil belajar siswa yang dipaparkan Gambar 2, menunjukkan bahwa ketuntasan belajar siswa telah melebihi $80 \%$. Hal ini berarti bahwa indikator keberhasilan yang ditentukan telah tercapai. Meskipun diketahui sebanyak $11,76 \%$ siswa atau sebanyak 4 dinyatakan tidak tuntas, namun ketuntasan yang telah mencapai $80 \%$ telah memenuhi syarat keberhasilan dari penelitian ini. Berdasarkan hal tersebut, maka penelitian ini dapat dikatakan berhasil. Adapun ke 4 siswa yang tidak tuntas tersebut merupakan siswa yang memang sulit untuk memahami materi, sehingga ke 4 siswa tersebut membutuhkan bimbingan secara khusus yang dilakukan di luar penelitian ini.

Aktivitas siswa pada siklus II diukur dengan menggunakan lembar observasi. Selama kegiatan pembelajaran berlangsung di Siklus II baik pada pertemuan I maupun pada pertemuan II dilakukan pengamatan untuk mengetahui dan mengukur aktivitas siswa dalam proses pembelajaran. Penghitungan aktivitas siswa pada siklus II sama seperti pada siklus I.

Aktivitas siswa dalam mengikuti pembelajaran dengan model PBL disajikan pada Tabel 5.

Tabel 5 Hasil Observasi Aktivitas Siswa Mengikuti Pelajaran Menggunakan Model PBL Siklus II

\begin{tabular}{|c|c|c|c|}
\hline Pertemuan & $\begin{array}{c}\text { Total } \\
\text { skor }\end{array}$ & $\begin{array}{c}\text { Nilai } \\
\text { Aktivitas }\end{array}$ & Kriteria \\
\hline 1 & 18 & $90 \%$ & Amat Baik \\
\hline 2 & 19 & $95 \%$ & Amat Baik \\
\hline Rata-Rata & $\mathbf{1 8 , 5}$ & $\mathbf{9 2 . 5 \%}$ & Amat Baik \\
\hline
\end{tabular}

Tabel 5 menunjukkan nilai aktivitas siswa selama mengikuti pembelajaran pada siklus II. Berdasarkan Tabel 5, dapat diketahui adanya peningkatan aktivitas. Secara garis besar, baik pada pertemuan 1 dan pertemuan 2 diperoleh nilai yang berada pada kategori amat baik. Hal ini menunjukkan bahwa aktivitas siswa selama mengikuti pembelajaran tergolong baik, dengan demikian penerapan model pembelajaran PBL dapat dilakukan dengan baik.

Pengukuran minat belajar juga dilakukan pada akhir siklus II. Sama seperti pada siklus I, pengukuran minat belajar pada siklus II dilakukan dengan 
menggunakan angket minat yang selanjutnya diukur dengan menggunakan rumus yang sama pada perhitungan minat siklus I. Berdasarkan hasil analisis minat siswa setelah mengikuti pembelajaran PBL pada siklus II, dapat diketahui bahwa nilai minat siswa adalah $78,16 \%$. Nilai ini berada pada kategori baik. Berdasarkan hasil tersebut maka model PBL dapat dikatakan mampu meningkatkan minat belajar siswa.

\subsection{Analisis Hasil}

Hasil pembahasan menunjukkan bahwa adanya peningkatan terhadap ketuntasan belajar siswa, minat belajar siswa, dan aktivitas belajar siswa. Peningkatan ketuntasan belajar siswa terlihat dari perbandingan hasil ketuntasan belajar dari kondisi awal, siklus I, hingga siklus II. Adanya peningkatan dari kondisi awal ke siklus II sebesar 41, 18\% menunjukkan keberhasilan dalam penerapan model pembelajaran PBL pada siswa kelas X SMA N 1 Bengkayang. Keberhasilan penelitian ini mendukung teori dari (Rusman, 2016) yang menyatakan bahwa model PBL bertujuan untuk meningkatkan penguasaan materi ajar serta meningkatkan keterampilan pemecahan masalah di mana masalah yang diberikan dikemas sesuai dengan materi ajar, hal ini bertujuan agar permasalahan yang harus diselesaikan mudah dipahami siswa. Hal tersebut dapat mendorong siswa untuk aktif berpikir sehingga membantu siswa dalam meningkatkan hasil belajarnya.

Selain peningkatan hasil belajar, minat belajar siswa kelas X di SMA N 1 Bengkayang juga mengalami peningkatan yakni sebesar $10,51 \%$. Peningkatan ini menunjukkan keberhasilan dalam penerapan model PBL di kelas tersebut. Hasil ini juga mendukung hasil pendapat dari (Janah, et al., 2018) bahwa melalui PBL siswa mampu mengikuti pembelajaran yang dapat mengembangkan keterampilan berpikir yang dituangkan dalam kemampuan mengatasi masalah. Adanya kegiatan pemecahan masalah yang dikemas dalam kegiatan kelompok menjadikan siswa lebih antusias dalam belajar sehingga meningkatkan ketertarikan siswa dalam belajar.

Hasil observasi pada siklus I menunjukakan bahwa proses pembelajaran dengan menerapkan PBL sudah berjalan dengan baik, meskipun ada beberapa langkah pembelajaran yang terlewatkan, namun secara garis besar pembelajaran telah berjalan dengan lancar. Hal ini dibuktikan dengan nilai aktivitas pada siklus I yakni sebesar $80 \%$, nilai tersebut berada pada kategori amat baik. Hasil observasi pada siklus II menunjukkan adanya peningkatan baik aktivitas siswa yang dibuktikan dengan nilai aktivitas belajar sebesar 92,5\%, hal tersebut membuktikan bahwa pembelajaran PBL dapat dilaksanakan dengan baik. Hasil ini sejalan dengan hasil penelitian dari (Rahmat, 2018) yakni melalui penerapan model PBL terbukti dapat meningkatkan hasil belajar siswa. Peningkatan aktivitas belajar juga menunjukkan kesesuaian dengan hasil penelitian yang dilakukan oleh (Naisyah, 2019), di mana aktivitas belajar siswa mengalami peningkatan setelah mengikuti pembelajaran dengan PBL.

Hasil penelitian ini juga telah menjawab indikator keberhasilan yang ditentukan, yaitu hasil belajar siswa dikatakan berhasil apabila $80 \%$ dari 34 siswa telah berhasil mencapai standar Kriteria Ketuntasan Minimal (KKM). KKM. Dalam penelitian yang telah dilakukan dapat di ketahui bahwa ketuntasan siswa pada siklus II telah mencapai $88,24 \%$ yang artinya ketuntasan tersebut telah melampaui dari indikator keberhasilan yang ditentukan. Hasil penelitian ini juga telah menjawab hipotesis penelitian yang di tetapkan bahwa penggunaan model pembelajaran PBL (Problem Based Learning) dalam pembelajaran Ekonomi dapat meningkatkan minat, aktivitas dan hasil belajar siswa kelas $\mathrm{X}$ di SMA N 1 Bengkayang.

Keberhasilan penelitian ini sekaligus memperkuat keberhasilan penelitian-penelitian yang telah disebutkan di atas dan juga mendukung teori mengenai model pembelajaran PBL sebagaimana dipaparkan sebelumnya, namun penelitian ini berbeda dengan penelitianpenelitian sebelumnya, meskipun model pembelajaran yang digunakan sama namun subyek, tempat, dan waktu pelaksanaan penelitian ini berbeda dengan penelitian lainnya.

Hasil penelitian ini menunjukkan bahwa penerapan model pembelajaran PBL pada pembelajaran ekonomi dapat meningkatkan aktivitas, minat, dan hasil belajar siswa kelas $\mathrm{X}$ di SMA N 1 Bengkayang. Berdasarkan hasil ini, maka dapat dijadikan bahan acuan untuk meningkatkan kemampuan hasil belajar lainnya. Penerapan model pembelajaran PBL dalam pembelajaran sangat membantu siswa dalam memahami materi yang diajarkan, siswa dikondisikan untuk mampu memecahkan masalah. Hal ini mendorong siswa untuk memahami materi pembelajaran dengan lebih mendalam, agar siswa mampu menggunakan pemahamannya untuk memecahkan masalah. Model pembelajaran PBL juga membantu guru dalam menyampaikan materi terlebih lagi dengan dipadukan media powerpoint, guru dapat menggunakan permasalahan yang bersinggungan dengan kehidupan sehari-hari siswa yang dikaitkan dengan materi ajar. Hal tersebut akan membantu siswa untuk lebih memahami dan mengerti tujuan dari pembelajaran yang dilakukan sehingga siswa tidak hanya belajar teori semata namun lebih kepada kegunaannya dalam kehidupan sehari-hari. Penggunaan media powerpoint yang dipadukan dengan langkah-langkah dalam model PBL menunjukkan keselarasan yakni media ini turut membantu penyampaian materi, serta menarik perhatian siswa. Langkah-langkah kegiatan pemecahan masalah yang dilakukan dalam kegiatan kelompok membuat siswa dapat leluasa memberikan ide jika dibanding dengan penyelesaian soal secara individu. Penyusunan laporan kelompok yang dikerjakan bersama anggota kelompok menunjukkan hasil yang bervariasi dan lebih menarik. Siswa mampu mengkreasikan ide serta pemahamannya terkait materi ajar. Pemecahan masalah 
dapat diselesaikan dengan baik melalui kegiatan kelompok, antusias siswa, serta keterlibatan siswa selama proses pembelajaran lebih baik ketika penerapan model PBL dilakukan. Temuan ini menunjukkan bahwa model PBL yang dikemas dalam kegiatan kelompok serta penggunaan media powerpoint memberikan dampak yang baik terkhusus dalam peningkatan hasil, aktivitas, dan minat belajar.

\section{KESIMPULAN}

Hasil analisis pada pembahasan menunjukkan adanya peningkatan ketuntasan hasil belajar, minat belajar dan aktivitas belajar dari kondisi awal hingga ke siklus II. Peningkatan belajar yang didapat pada siklus II telah mencapai indikator keberhasilan yang ditentukan yakni hasil belajar pada siklus II sebesar meningkat menjadi $88,24 \%$ dari $70,59 \%$, sedangkan minat belajar siswa siklus I sebesar $67,65 \%$ meningkat menjadi $78,16 \%$ pada siklus II dan aktivitas belajar siswa sebesar $80 \%$ pada siklus I meningkat menjadi $92,5 \%$ pada siklus II. Peningkatan tersebut menunjukkan keberhasilan penerapan model pembelajaran PBL, dengan demikian dapat disimpulkan bahwa peningkatan aktivitas, minat, dan hasil belajar ekonomi siswa melalui model pembelajaran PBL telah berhasil dilakukan.

\section{SARAN}

Untuk penelitian dengan judul atau topik yang mengacu kepada penelitian ini, diharapkan memperhatikan langkah-langkah model PBL dan memperhatikan karakteristik siswa agar proses pembelajaran dapat berjalan dengan baik serta dapat memberi dampak pada hasil penelitian yang baik. Model PBL juga dapat dijadikan kajian dalam penelitian dengan pendekatan kuantitatif maupun kualitatif. Bagi guru sebagai pengajar dapat menerapkan model PBL dengan dipadukan media ajar sehingga penerapn model PBL dapat lebih efektif dan dapat mencapai tujuan pembelajaran yang diharapkan.

\section{DAFTAR PUSTAKA}

Apriyani, P., Margiati, K., \& Anasi, P. T. 2019. Pengaruh Penerapan Model PBL Terhadap Hasil Belajar Siswa Kelas X IPS MAN 2 Pontianak. Jurnal Pendidikan dan Pembelajaran Katulistiwa, 8(1), 1-8.

Eko. 2016. Ilmu-Ilmu Sosial SMA dan MA Kelas X. Jakarta: CV Merah Putih.

Inayah, R., Martono, T., \& Sawiji, H. 2013. Pengaruh Kompetensi Guru, Motivasi Belajar Siswa, dan Fasilitas Belajar terhadap Prestasi Belajar Mata Pelajaran Ekonomi Pada Siswa Kelas XI IPS SMA Negeri 1 Lasem Jawa Tengah Tahun Pelajaran 2011/2012. Jurnal Pendidikan Insan Mandiri, 1(1), 1-13.

Janah, M. C., Widodo, A. T., \& Kasmui. 2018. Pengaruh Model Problem Based Learning Terhadap Hasil
Belajar dan Keterampilan Proses Sains. Jurnal Inovasi Pendidikan Kimia, 12(1), 2097-2107.

Magdalena, R. 2016. Penerapan Model Pembelajaran Problem Based Learning (PBL) serta Pengaruhnya terhadap Hasil Belajar Biologi Siswa SMA Negeri 5 Kelas XI Kota Samarinda Tahun AJaran 2015. Seminar Nasional XIII Pendidikan Biologi UNS 299 SP-005-010. 13, pp. 299-306. Solo: Proceeding Biology Education Conference.

Mastufah. 2019. Peningkatan Motivasi Hasil Belajar Ekonomi Melalui Model Pembelajaran Student Centered Learning. Attractive: Inovative Education Journal, 1(1), 40-53.

Mulyasa. 2009. Standar Kompetensi dan Sertifikasi Guru. Bandung: PT Remaja Rosdakarya.

Murdinar, H. E., Wahyono, H., \& Haryono, A. 2017. Pengembangan Pembelajaran Ekonomi Untuk Meningkatkan Perilaku Produktif Siswa. Jurnal Pendidikan: Teori, Penelitian, dan Pengembangan, 2(1), 73-77.

Naisyah. 2019. Penerapan Model Problem Based Learning dalam Meningkatkan Hasil Belajar Ekonomi Kelas X3 SMA Negeri Bulukumba. Jurnal Ekonomi dan Pendidikan, 2(1), 10-14.

Nur, B. N. 2018. Penerapan Model Pembelajaran Problem Based Learning (PBL) Untuk Meningkatkan Hasil Belajar Geografi Kelas XI IPS 1 SMA Negeri 12 Makassar. La Geografia, 17(1), 16-29.

Peraturan Pemerintah Republik Indonesia Nomor 17, Nomor 17 (Tahun 2010).

Peraturan Pemerintah Republik Indonesia Nomor 32, Nomor 32 (Mei 7, Tahun 2013).

Purnamasari, K. N. 2016. Penerapan Strategi Learning Start With a Quation (LSQ) untuk Meningkatkan Aktivitas dan Hasil Belajar Siswa pada Mata Pelajaran Ekonomi di Kelas X-7 SMA Laboratorium Undiksha Singaraja Tahun Ajaran 2015/2016. Jurnal Program Studi Pendidikan Ekonomi (JPPE), 7(2), 1-12.

Purwanto, N. 2017. Psikologi Pendidikan. Bandung: Remaja Rodaskarya.

Putri, K., Djaja, S., \& Suyadi, B. 2017. Pengaruh Minat Belajar dan Kecerdasan Emosional Terhadap Prestasi Belajar Siswa Kelas XI IPS SMA Negeri Prajekan Kabupaten Bondowoso Tahun Ajaran 2016/2017. Jurnal Pendidikan Ekonomi: Jurnal Imiah Ilmu Pendidikan, Ilmu Ekonomi, dan Ilmu Sosial, 11(1), 67-74.

Rahmat, E. 2018. Penerapan Model Pembelajaran Problem Based Learning (PBL) untuk Meningkatkan Prestasi Belajar Siswa. Jurnal Penelitian Pendidikan, 144-159.

Rusman. 2016. Model-Model Pembelajaran: Mengembangkan Profesionalisme Guru (2 ed.). Jakarta: PT Raja Grafindo Persada. 
Slameto. 2015. Belajar dan Faktor-Faktor yang Mempengaruhinya. Jakarta: Rineka Cipta.
UCAPAN TERIMA KASIH

Ucapan terima kasih diberikan kepada guru kelas $\mathrm{X}$ SMA N 1 Bengkayang yang telah berpartisipasi sehingga penelitian ini dapat berjalan dengan baik, serta seluruh siswa kelas X SMA N 1 Bengkayang sebagai subjek penelitian. Ucapan terima kasih juga dipersembahkan untuk STIM Shanti Bhuana atas dukungan serta hibah yang diberikan sehingga penelitian ini dapat berjalan dengan lancar. 